\title{
EDUCAÇÃO, RELAÇÕES DE GÊNERO E SEXUALIDADES: EXPERIÊNCIAS DE ESTUDANTES DE PEDAGOGIA
}

Roney Polato de Castro*

\begin{abstract}
RESUMO
O artigo apresenta parte das análises desenvolvidas em uma pesquisa de doutorado. $\mathrm{O}$ foco da pesquisa e a discussão do artigo são as experiências de formação docente inicial em uma disciplina do curso de Pedagogia que aborda as temáticas de relações de gênero e sexualidades. A pesquisa tomou como material de análise os diários de bordo que as estudantes produziram a partir da disciplina. Para este artigo foram selecionados excertos narrativos nos quais as estudantes apresentam questões que lhes instigam, seja no contato com as escolas, seja em suas famílias. Conclui-se que a disciplina em questão produz certos modos de as estudantes analisarem seu cotidiano, suas relações pessoais e os acontecimentos presenciados nas escolas, problematizando significados hegemônicos associados aos gêneros e sexualidades.
\end{abstract}

Palavras-chave: Formação docente inicial. Relações de gênero. Sexualidades. Narrativas. Experiência.

\section{ABSTRACT \\ EDUCATION, GENDER RELATIONS AND SEXUALITIES: EXPERIENCES OF PEDAGOGY STUDENTS \\ The article presents part of the analysis developed in a doctoral research. The focus of the research and the discussion of the article are the experiences of initial docent formation in a subject of the Pedagogy course, which approaches themes such as relations of gender and sexualities. The research had as a source of analysis the logbooks produced by students from the discipline. To produce this article we utilized narrative excerpts in which students presented questions that instigate themselves, both concerning the contact with schools and with their families. One can conclude that the discipline in question produces certain modes for the students to analyze their quotidian, their personal relations and the presence of such occurrences inside the school, problematizing hegemonic meanings associated with genders and sexualities.}

Keywords: Initial docent formation. Relations of gender. Sexualities. Narratives. Experience.

\footnotetext{
* Doutor em Educação pela Universidade Federal de Juiz de Fora (UFJF). Professor da Faculdade de Educação e do Programa de Pós-Graduação em Educação da Universidade Federal de Juiz de Fora (UFJF). Endereço: Campus Universitário. Rua José Lourenço Kelmer, s/n, São Pedro. Juiz de Fora-MG. CEP: 36036-900. roneypolato@gmail.com
} 


\section{RESUMEN}

\section{EDUCACIÓN, RELACIONES DE GÉNERO Y SEXUALIDADES: EXPERIENCIAS DE ESTUDIANTES DE PEDAGOGÍA}

El artículo presenta parte de los análisis desarrollados en una investigación doctoral. El foco de la investigación y de la discusión del artículo es la formación inicial del profesorado desde las experiencias en una disciplina del curso de pedagogía que aborda las temáticas de las relaciones de género y sexualidad. La investigación tomó como material de análisis los cuadernos de bitácora que las estudiantes producen a partir de la disciplina. Para este artículo se seleccionaron fragmentos narrativos en los cuales las estudiantes presentan preguntas que les provocan, sea en el contacto con las escuelas, sea en sus familias. Llegamos a la conclusión de que la disciplina en cuestión produce ciertos modos de las estudiantes analizar su vida cotidiana, sus relaciones personales y los acontecimientos presenciados en las escuelas, cuestionando significados hegemónicos asociados a los géneros y sexualidades.

Palabras claves: Formación inicial del profesorado. Relaciones de género. Sexualidades. Narrativas. Experiencia.

\section{Introdução}

Este artigo foi construído com base em uma pesquisa de doutorado cujo foco está nos atravessamentos de experiências e na constituição de $s u$ jeitosdocentes ${ }^{1}$ em processos de formação docente, produzidos a partir de uma disciplina - Tópicos Especiais Gênero, Sexualidade e Educação (TEGSE) - que aborda as discussões sobre as relações de gênero, as sexualidades e a educação em um curso de Pedagogia de uma universidade pública federal. A categoria "experiência" aparece como fio condutor para pensar nos modos como os sujeitos se constituem no movimento dos dispositivos de subjetivação dos currículos de formação docente. O conceito de experiência é tomado como modo de atravessamento, no sentido de algo que nos atravessa, que nos passa, penetra nossas concepções, valores, saberes; ao nos atravessar a experiência agita, mistura, desorganiza, pode desfazer barreiras.

As inquietações que constituem o mote de discussão deste artigo se produziram com as escritas narradas pelas estudantes em "diários de bordo", 2

1 Ao longo do texto utilizo termos ligados e em itálico para expressar que eles se colocam em relação, em atravessamento, constituindo-se mutuamente, sendo necessário pensá-los em conjunto.

2 O termo 'diário de bordo' vem sendo utilizado em pesquisas, práticas de formação docente e educativas, em diferentes contextos e sob diferentes perspectivas. Para ampliar a discussão, consultar a tese Experiência e constituição de sujeitosdocentes: relações de gênero, sexualidades e formação em Pedagogia (CASTRO, 2014), que serviu de fonte para este artigo. artefatos constituídos na disciplina TEGSE para registrar os movimentos de pensamento, os sentimentos, as provocações instituídas pelas aulas. Diários de bordo acompanham os/as viajantes, são documentos de viagem que registram acontecimentos, situações, sentimentos e pensamentos de quem os vivenciou. Utilizamos o diário como um documento que registrou o percurso pelos movimentos por/entre diferentes ideias, os deslocamentos por/ entre crenças e valores, os caminhos percorridos pelos textos, imagens, narrativas e memórias, produção de experiências de pensamento e de vida. A partir deles podemos pensar: que experiências são produzidas por estudantes de Pedagogia em uma disciplina que trata das relações de gênero, sexualidades e educação? Como essas experiências se materializam nas escritasnarrativas das estudantes nos seus diários de bordo? Considerando a experiência como uma viagem, foi proposto a cada semestre que as estudantes narrassem nos seus diários os acontecimentos, situações, sentimentos, pensamentos. Documento que permitiu que eu - professorpesquisador - acompanhasse os processos subjetivos de formação a partir das provocações que os assuntos tratados na disciplina colocaram em funcionamento durante as aulas e para além delas.

Os diários de bordo serviram para anotações sobre as aulas, para transcrição de fragmentos dos textos lidos, registro das palavras do professor ou 
das colegas. Foram as estudantes que selecionaram o que ia para o diário, o que lhes parecia mais significativo, o que lhes tocava. Observei que os temas enfatizados nas aulas e textos, nos debates e nos relatos das colegas são potentes para o processo de pensar e construir os diários. Na escrita elas se recordavam das aulas, textos, vídeos, debates, retomavam esses elementos e faziam algo com eles, um arranjo particular, uma composição. Outro aspecto a ressaltar é que a escrita de si (FOUCAULT, 2006) do diário é uma escrita para um outro, uma escrita que narra a si mesma para o outro e torna-se um convite a pensar junto, a recordar as aulas e debates, um convite a também compor alguma coisa a partir da escrita. Tomei esse convite particularmente, já que foram raras as ocasiões em que outros leram os diários, além de mim, professorpesquisador. Nas narrativas de si das estudantes eu também me vi, me analisei, pensei nas aulas, nos debates e em tudo que se produziu na disciplina, pensei em minha própria constituição de sujeitopesquisador.

Venho tomando as escritasnarrativas como constitutivas de subjetividades, capazes de nos transformar no que somos, ou seja, a partir das histórias que contamos, inclusive sobre nós mesmos(as), nos formamos e nos transformamos continuamente. Desse modo, as narrativas são mais que a descrição de eventos experienciados ou modelos explicativos, as performances narrativas são ações de construção da vida social, atos que funcionam para realizar (ou para levar a efeito) aquilo que articulam (LOPES, 2009; MATTOS, 2010). Trata-se de uma transformação, de um trabalho de construção subjetiva que se abre à possibilidade de ser outro do que se é, "implica um entrelaçamento com as experiências sociais e com as vivências cotidianas em que figuram múltiplos personagens" (RAGO, 2011, p. 07).

$\mathrm{O}$ investimento analítico das experiências vividas na disciplina TEGSE e as categorias discutidas com a pesquisa mencionada anteriormente se dão a partir dos estudos de gênero e de sexualidade construídos com as perspectivas pós-estruturalistas, com especial enfoque para as contribuições dos estudos foucaultianos. Desses estudos, tomo por empréstimo as ferramentas analíticas que me auxiliam a pensar nos processos de subjetivação, nas experiências e narrativas, nas relações de saber-poder, nas relações de gênero, sexualidades e nos processos educativos como construções discursivas, sociais, culturais e históricas, que incidem sobre os sujeitos, tornando-os quem são, atribuindo-lhes certas posições na sociedade.

$\mathrm{O}$ artigo se organiza em torno de proposições teórico-analíticas. Primeiramente, delineando de que modos a categoria experiência é pensada e utilizada como ferramenta de análise, associando-a à formação docente e tomando as contribuições dos filósofos Jorge Larrosa e Michel Foucault. Em seguida, breves ensaios analíticos construídos a partir das escritas das estudantes de Pedagogia nos diários de bordo, com foco em registros nos quais elas problematizam cenas presenciadas nas escolas e também pensam suas relações com familiares e outros sujeitos.

\section{Experiência, educação, formação docente}

Experiência não é um fato ou algo facilmente identificável, tampouco é um conceito claramente definido. Larrosa (2014) dispõe a experiência junto ao que nos acontece e que nos faz tremer. Experienciar é viver e ser constituído pela experiência, a arte de viver a experiência e viver a transformação pela experiência. A experiência é o que nos acontece quando não sabemos o que nos acontece (LARROSA, 2014). Algo que não depende de nós, nem de nosso saber, poder ou vontade. Algo que nos acontece e sobre o que temos vontade de falar e de continuar falando, algo sobre o que temos vontade de pensar, e de continuar pensando. A experiência é sempre de alguém, portanto, é subjetiva, contextual, provisória. Se a experiência é o que me acontece, ao me acontecer ela me forma e me transforma, me constitui, me faz como sou. Assim, a experiência tem a ver também com o que nos faz ser o que somos e o que transforma o que somos, convertendo isso em outras coisas (LARROSA, 2014).

Larrosa $(2005$, p. 67) diz que a experiência "é um passo, uma passagem" que contém "o "ex' do exterior, do exílio, do estranho, do êxtase" e também “o 'per' de percurso, do 'passar através', da viagem, de uma viagem na qual o sujeito da experiência se prova e se ensaia a si mesmo". Essa experiência não se dá sem risco: "no experiri está o 
periri, o periculum, o perigo". O percurso viajante de produção de si, o percurso perigoso de construir uma experiência de si, de produzir um outro, um movimento incessante de transformação. Envolve, portanto, subjetivação e dessubjetivação.

Ao atravessar a pesquisa que subsidia este artigo, o "conceito" de experiência me possibilitou pensar que a relação das estudantes de Pedagogia com a disciplina TEGSE poderia ser uma experiência, não no sentido generalizante, mas de cada uma delas, portanto, uma "passagem" singular, algo que acontece, que inquieta e pode produzir vontades de pensar, de falar, de sentir e de agir, ou como diz Larrosa (2014), de vibrar outros cantos, em outras experiências. Experiência que forma e transforma, ainda que não haja garantias, porque não há uma experiência a ser vivida do mesmo modo por todas. Se a experiência é uma relação com algo que me passa, que acontece a mim, com as aulas da disciplina TEGSE as estudantes podem, em relação às problematizações, formar-se ou transformar-se, produzir suas próprias problematizações. Importa menos o que as aulas dizem sobre os autores(as), os conceitos, e mais como as estudantes, em relação com as palavras e conceitos desses(as) autores(as), podem formar e transformar suas palavras, suas ideias, seus saberes. Como as aulas podem ajudar a pensar e sentir o que ainda não foi possível pensar e sentir, o que não se queria pensar e sentir. Nessa experiência, as estudantes podem se encontrar com suas próprias fragilidades, vulnerabilidades e ignorâncias, sua própria impotência, o que escapa ao que sabem, ao que podem, às suas vontades. E fazer experiência, nesse sentido, é atenção, escuta, abertura, disponibilidade, sensibilidade, exposição.

A perspectiva de experiência delineada neste artigo também vai ao encontro das teorizações foucaultianas. Em seus estudos, Foucault (2001) abarca três eixos de experiência: o saber, o poder e as formas de subjetividade. No atravessamento desses eixos, considerando-os como conceitos, Foucault (2001) trabalha para tornar visíveis as condições concretas de conformação dos sujeitos a um tipo "particular" de experiência, ou seja, a experiência é o que leva os sujeitos a se reconhecerem como tal, a partir de uma experiência historicamente singular - a experiência da loucura, da delinquência, da sexualidade. Assim, essa experiência histórica, constituída na trama de discursos e práticas sociais, é que cria o sujeito, os modos de subjetivação, os jogos de verdade por meio dos quais o ser se constitui historicamente como podendo e devendo ser pensado.

Nos estudos de Foucault, a experiência também aparece como modo de dessubjetivação, como "experiência limite", possibilidade de transformação de si. Como argumenta Ortega (1999), a experiência constituiria algo do qual se sai transformado, uma práxis espiritual ou ascética, ou seja, transformações que o sujeito deve experimentar para alcançar outra forma de ser. Foucault (2009, p. 12), a partir da leitura de Nietzsche, Bataille e Blanchot, vai pensar a experiência como algo capaz de desprender o sujeito de si mesmo, que possibilita "desgarrar al sujeto de sí mismo, de manera que no sea ya el sujeto como tal, que sea completamente otro de sí mismo, de modo de llegar a su aniquilación, su disociación.". Tal experiência seria um "emprendimiento de desubjetivación" exatamente porque "desgarra al sujeto de si".

Formação docente e experiência: nesse atravessamento, alguma experiência pode se produzir na relação com a disciplina TEGSE. Algo pode passar, algo pode acontecer a cada uma das estudantes, pode modificar seus modos de ser, de pensar, de sentir. A palavra "pode" é uma expressão condicionante que se ajusta à proposta do meu argumento de pensar a "possibilidade" da experiência e não a sua imposição. Há transformações porque somos sujeitos e porque nosso processo constitutivo passa por formas históricas de subjetivação e dessubjetivação. Porém, para cada pessoa há um processo de dessubjetivação, uma experiência singular e contextual que se faz na relação com aquilo que acontece, que toca, que nos passa. No caso das discussões deste artigo, nos subjetivamos a partir de formas históricas de docência, de discursos e práticas que constroem as/os docentes que somos ou que desejamos ser e como fazemos essa experiência com a educação escolar a partir da docência. Estou, portanto, deliberadamente, associando formação docente com experiência, com a possibilidade de que ela seja uma formaçãoexperiência que possibilite pensar no que somos, no que viemos nos tornando, nos modos como estamos assujeitados a certos discursos e nas liberdades que podemos constituir diante deles. 
A formação docente inicial ${ }^{3}$ se insere no conjunto de mecanismos vinculados a contextos sociais, culturais e históricos específicos, que colocam em ação certas estratégias por meio das quais as estudantes de Pedagogia em formação produzem ou transformam a experiência que têm de si mesmas, os modos como se tornam objetos para si mesmas e como suas experiências com os gêneros e as sexualidades são elaboradas e reelaboradas a partir das relações em que elas pensam a si mesmas. Tratando especificamente da disciplina TEGSE, ela funciona como um convite - aceito em maior ou menor dimensão e às vezes recusado - para que as estudantes passem a olhar para si mesmas. Desse modo, com Larrosa (2002), problematizo a ideia de que as práticas de formação seriam apenas mediadoras do desenvolvimento dos sujeitos, fazendo a opção por acreditar que as pedagogias são práticas que têm papel produtivo. Pensar na possibilidade de uma disciplina que integre o currículo dos cursos de formação inicial universitária é, nesse sentido, um investimento na produção de sujeitosdocentes que estejam sensíveis às questões que envolvem as relações de gênero e as sexualidades no interior do espaço escolar e para além de seus "muros". Ao destacar esse processo não estou apontando a disciplina como uma formação "mais correta" ou "mais adequada" para atuar frente às questões que envolvem os gêneros e as sexualidades nas escolas, mas uma formação que investe na possibilidade de pensar diferentemente, olhar a partir de novos ângulos, exercitar o pensamento diante de situações cotidianas para as quais não há uma resposta a priori.

Ao apostar na ideia de que a formação docente se constitui em mecanismo que funciona como "técnica de si" (FOUCAULT, 2006), afasto-me de um absolutismo dessa formação, como se ela instituísse um processo definitivo e garantidor da "fabricação" de um sujeito completamente formado, capaz de resolver os problemas educacionais, dar conta das "mazelas sociais". Tomo aqui a formação docente enquanto processo de produção de sujeitosdocentes, composto por uma diversidade de mecanismos, dentre os quais situo as narrativas, em especial as escritas.

\footnotetext{
3 Poderia dizer o mesmo em relação aos processos de formação docente continuada, bem como aqueles que ocorrem nos mais diversos cursos de licenciatura.
}

A disciplina TEGSE é, como foi dito, um convite às estudantes de Pedagogia para pensarem a si mesmas, suas relações com outros e com o mundo e para construírem narrativas desses processos de subjetivação. Tal desafio é lançado não para manter "tudo como está", mas para poder pensar diferentemente, agir diferentemente, constituir uma ética e uma estética da existência (FOUCAULT, 2006). $\mathrm{Na}$ constituição de sujeitosdocentes por meio da complexa articulação de discursos e práticas, a experiência se faz pelos modos como vamos sendo subjetivados(as) na "passagem" pela existência, tomando o sujeito "como forma a compor, como uma permanente transformação de si, como o que está sempre por vir" (LARROSA, 2005, p. 67). Assim, considero relevante problematizar essa constituição a partir das normatizações das sexualidades e das relações de gênero, nos jogos de poder em que se arquitetam formas de transgressões e resistências.

Larrosa (2014) diz que a experiência é algo que nos passa, que nos acontece. Assim, a experiência pode nos transformar na medida em que nos atravessa, nos provoca a pensar naquilo que somos, nos faz sair do lugar e nos movimentar pelo vivido. E assim, nos impede de sermos sempre os mesmos, nos dessubjetiva e nos transforma em outros (FOUCAULT, 2009). Para que sejamos capazes de fazer da experiência uma ferramenta de desconstrução de nós mesmos(as) é preciso que ela se torne objeto de pensamento, de problematização, algo que é possível ao empreendermos um movimento de narração. Assim, narrar as experiências nos diários de bordo pareceu possibilitar às estudantes entrar em contato com elas, dar-lhes um lugar na trajetória do vivido. Como argumenta Sarlo (2007, p. 25), a narração

\section{[...] inscreve a experiência numa temporalidade que não é a de seu acontecer (ameaçado desde seu próprio começo pela passagem do tempo e pelo irrepetível), mas a de sua lembrança. A narração também funda uma temporalidade que a cada repetição e a cada variante torna a se atualizar.}

Nesse sentido, a memória é tomada como dimensão temporal subjetiva, ou seja, a restauração da experiência intimamente relacionada à subjetividade. As experiências das estudantes de Pedagogia são inscritas no presente a partir das memórias, pensando que os esquecimentos e as 
lembranças nos constituem. Portanto, não é uma simples repetição de fatos, mas uma narrativa de si como exercício de constituição de si mesmo.

Ao trazer para este texto a discussão aqui tecida, ressaltam-se as condições singulares de funcionamento de uma disciplina acadêmica que integra o currículo universitário, e seus efeitos na formação das estudantes, entendendo que ela vai além da preparação técnica para a docência, estando implicada com a produção de sujeitos e de experiências. Durante as aulas da disciplina e nos diários de bordo, as estudantes relatam situações em que demonstram associar as discussões com o cotidiano, passando a olhar de modo diferente para elas, algo que antes estava naturalizado. Observo, desse modo, que a disciplina pode estar produzindo sujeitos com outros olhares sobre as relações de gênero e sexualidades. Em se tratando da formação docente, essa ideia pode ser produtiva, na medida em que ao envolver-se na problematização de valores e concepções naturalizadas, as estudantes podem "dar um passo atrás", uma liberdade de separar-se do que faz e estabelecê-lo como um objeto de pensamento (MARSHALL, 2008), amparadas pelo grupo, pelo professor, pelo diário e pelas estratégias utilizadas nas aulas.

Uma disciplina que fez certos empreendimentos sobre as estudantes: problematizar, desnaturalizar, desconstruir, instalar a dúvida e a suspeita, modificar os modos de se relacionar com temas ainda pouco debatidos na formação inicial docente. Dois movimentos propiciados pela disciplina: uma transformação no modo com que as estudantes se relacionavam com as temáticas discutidas e uma incorporação de certos olhares sobre as mesmas, que modificavam o modo de ver o cotidiano. As atividades propostas - escrever narrativas, debater temas, ler textos, analisar imagens -, a fim de que as estudantes passassem a se conduzir de outros modos, parecem ter possibilitado uma problematização de si mesmas enquanto sujeitos assujeitados a um código moral. Materializou-se na escrita parte de um processo de constituição de si, colocado no movimento por subjetividades desejáveis elaboradas a partir dos jogos de verdades propostos na disciplina.

Desconstruir concepções enraizadas, derrubar valores construídos são processos que apareceram como exercícios "dolorosos" porque perturbavam o conhecido, o familiar, o comum. As expectativas iniciais da disciplina - Como trabalhar esses temas na escola? Como trabalhar esses temas com as crianças? Como ter uma postura "natural" diante desses temas na escola? - movimentavam algumas estudantes e paralisavam outras. Ou seja, quando as situações cotidianas adentravam a aula e incitavam um mergulho nas inúmeras possibilidades de pensá-las, algumas estudantes esperavam a resposta pronta, a solução a ser dada em cada caso. Entretanto, tomando a problematização como ferramenta, conseguimos ampliar as perguntas e apontar para múltiplos caminhos. Tal movimento é parte do exercício das estudantes sobre si mesmas, suas ações, seus comportamentos, seus pensamentos, procurando atingir certo modo de ser (FOUCAULT, 2006). Os registros das estudantes, provocados pelas técnicas de si da disciplina, apontam para uma compreensão de sujeito como "transformável" e "modificável", um sujeito que se constrói, que se dá regras de existência e conduta, que se forma através de exercícios, das práticas, das técnicas (GROS, 2004, 2008). Fica evidenciado um processo de investimento sobre si, em se elaborar e se transformar, visando constituir um ethos, um modo de viver com as problematizações da disciplina. É isso que problematizo nas discussões a seguir.

\section{"[...] o menino ficava igual a uma bichinha na fila de entrada"}

Diário, vou te contar uma situação que me deixou bastante intrigada nesta semana. Estava em uma escola de educação infantil e indo para a sala dos professores me deparei com a seguinte cena: um grupo de professoras fazendo comentários depreciativos em relação a um aluno que elas diziam ser 'viadinho'. As 'docentes' - entre aspas porque não sei se realmente elas merecem esta denominação - falavam, entre gargalhadas, que o menino ficava igual a uma bichinha na fila de entrada e que quando crescesse não escaparia de ser gay. Fiquei até com vergonha de ouvir as palavras delas em relação ao aluno. (ROBERTA, ${ }^{4}$ grifo do autor).

4 Os nomes das estudantes foram substituídos por pseudônimos, a fim de resguardar o anonimato na pesquisa e nas produções acadêmicas dela decorrentes. As estudantes foram previamente consultadas sobre sua participação na pesquisa, tendo sido acordado por meio de Termo de Compromisso devidamente assinado. 
As aulas da disciplina TEGSE se constituíram em espaços de narração das experiências vividas nos estágios, na relação com as escolas, associando-as às problematizações que empreendíamos sobre as relações de gênero e as sexualidades nos ambientes escolares. Processos de análise que se materializaram nas escritas que compuseram os diários de bordo. Situações que emergiam a partir dos saberes propostos pela disciplina, do jogo de verdades instaurado por ela (FOUCAULT, 2006). As estudantes fariam tais análises caso não estivessem cursando a disciplina? As situações destacadas seriam motivo de problematização? Que formaçãoexperiência se dá em outros âmbitos acadêmicos?

Em que outros espaços do curso de graduação as estudantes escreveriam a partir dessas experiências, produzindo narrativas de si? As situações como a que Roberta narra em seu diário ganharam contornos de debate em sala de aula, à medida que as demais estudantes relacionavam esses fatos às suas próprias experiências, construindo representações da docência. Roberta narra essa construção: “As 'docentes' - entre aspas porque não sei se realmente elas merecem esta denominação [...]"; "Fiquei até com vergonha de ouvir as palavras delas em relação ao aluno". Viver essa experiência e discuti-la no diário de bordo e em sala de aula parece movimentar as representações de Roberta em relação à docência (e me arrisco a dizer que o mesmo acontece com as demais estudantes). $\mathrm{O}$ argumento é de que esse processo fez com que Roberta se colocasse no lugar das professoras, identificando no comportamento delas uma espécie de "falha". Sem a pretensão de cair na armadilha do julgamento moral e situando as ações das professoras num contexto social, cultural e histórico que lhes possibilita dizer e agir da forma como Roberta observou, entendo que a estudante identifica uma atitude inadequada e parece distanciar-se dela. Nas aulas, situações como essa produziram questionamentos pelas próprias estudantes: por que esse comportamento das professoras não é adequado? Como nós agiríamos se fôssemos professoras dessa instituição? Como nós agiríamos com esse aluno? $\mathrm{O}$ que as professoras identificavam como sendo elementos de uma "sexualidade desviante" no menino? E se o menino se tornasse homossexual? Haveria problemas com isso?
Está em jogo o processo subjetivo de formaçãoexperiência, com uma escrita de si que acompanha a produção de subjetividades. As estudantes estão se constituindo em relação a um código moral pré-estabelecido, identificado nas atitudes das professoras, que lhes permite instituir lugares para o aluno: "viadinho", "bichinha", "gay". Do lugar de quem observa, pensa e escreve, a estudante também atribui um lugar às professoras - o da vergonha e da dúvida: poderiam mesmo ser chamadas de "docentes"?

Quando alguém xinga alguém de algo, por exemplo, quando chama essa pessoa de 'sapatão' ou 'bicha', não está apenas dando um 'nome' para esse outro, está julgando essa pessoa e a classificando como objeto de nojo. A injúria classifica alguém como 'poluidora', como alguém de quem você quer distância por temer ser contaminado. (MISKOLCI, 2012, p. 40 , grifo do autor).

As professoras possuem conhecimentos que organizam suas práticas pedagógicas. Elas se constituem por discursos culturais, sociais e históricos que atribuem comportamentos e marcas corporais distintas para sujeitos masculinos e femininos. Ultrapassar as fronteiras dessas distinções é entrar no jogo da exclusão, da inferiorização e da abjeção. Outras escritas nos diários remeteram a esse tipo de situação e podem fazer problematizar essa relação das escolas, da formação docente com a produção das sexualidades e das relações de gênero:

Boa noite, diário[...] aconteceu uma coisa que me deixou chateada hoje à tarde lá no meu trabalho: quando estávamos no parque com os alunos, uma funcionária começou a brincar com um aluno da minha sala. De repente, ele a estranhou e começou a fazer cara de choro. Como meu aluno é muito bonito e contém traços de mulher (puxando a mãe dele), a funcionária, sem pensar duas vezes, disse: 'Ixi... esse menino tem um jeitinho... quando crescer não sei não, hein!' 'Nossa', pensei, 'como assim?' Tipo, o garoto nem tem 2 anos ainda e a funcionária já determina que o menino será gay (homossexual) quando crescer. Estamos arraigados de preconceitos sobre os jeitos e características físicas das pessoas. (MAFALDA).

As professoras cujas atitudes são narradas por Roberta e por Mafalda evocam enunciados discursivos construídos na cultura para dar um lugar 
ao menino que parece ultrapassar as fronteiras dos gêneros, embaralhar gênero e sexualidade, de modo que o "choro" do menino se transforme em sinal de alerta para um possível "desvio". Roberta, Mafalda e suas colegas tiveram a oportunidade de problematizar esses enunciados nas aulas da disciplina TEGSE. Ao fazer suas análises nos diários de bordo, as estudantes se inserem no jogo de verdades, constituído por discursos que são conflituosos, que ao se embarrarem produzem um atrito, uma dissonância. Nas aulas discutimos que os distintos posicionamentos - mulher, homem, homossexual, heterossexual - são construídos por uma cultura e colocados em funcionamento nas relações sociais a partir de discursos advindos de múltiplas instâncias - famílias, escolas, religiões, ciências, mídias, instâncias jurídicas (LOURO, 2001). Tal discussão nos fez problematizar os enquadramentos atribuídos aos sujeitos que se aproximam e que se afastam das posições normativas - há um investimento sistemático na construção de uma naturalidade e de uma superioridade de certas categorias, como a heterossexualidade e a masculinidade. Classificar um menino nomeando-o de "viadinho", "bichinha", "gay" é inserir-se e inseri-lo na ordem dos discursos que aprisionam os sujeitos em invólucros normativos do gênero e da sexualidade, determinando limitações e imposições para sujeitos masculinos e femininos. Ao dizer "Ixi... sei não, hein! Esse menino tem um jeitinho... quando crescer não sei não, hein!”, a professora produz um sujeito, anuncia um processo, entra nos jogos performativos da linguagem. A performatividade, nesse caso, funciona "como a prática reiterativa e citacional pela qual o discurso produz os efeitos que ele nomeia." (BUTLER, 2001, p. 154). A professora parece reiterar a suposição de que sexo, gênero e sexualidade se inserem num sistema de mútua relação, que constrói gêneros e sexualidades inteligíveis, isto é, aqueles que mantêm relações de coerência e continuidade com esse sistema (BUTLER, 2003). Quando alguém "foge", "escapa" a esse sistema, a esse "destino pré-fixado", passa a ocupar o lugar da abjeção e a ele(a) são imputadas práticas de enquadramento que remetem à sua posição anormal, marginal.

Também Mafalda, a estudante que narra o fato, se insere nesse sistema, ao associar certas marcas corporais à definição do gênero (e consequente- mente, da sexualidade): "Como meu aluno é muito bonito e contém traços de mulher (puxando a mãe dele) [...]". A identificação de traços femininos em um menino pode justificar seu enquadramento em uma posição destoante, como "falha do desenvolvimento" ou "impossibilidade lógica", já que esse sujeito passa a não se conformar às normas culturais de inteligibilidade, considerando que "a diferença sexual, entretanto, não é, nunca, simplesmente, uma função de diferenças materiais que não sejam, de alguma forma, simultaneamente marcadas e formadas por práticas discursivas." (BUTLER, 2001, p. 153).

\section{"Fico triste de verdade por saber como as coisas são [...]"}

Com certa apropriação do pensamento de Foucault (2009), analiso que as narrativas dos diários de bordo não seriam "escrita-verdade", ou seja, uma escrita que materializa um processo fixo e linear de construção de um sujeito-substância. As narrativas estariam mais próximas de uma escritaexperiência, que ao se fazer funciona também como criadora do mundo. É, portanto, performativa, preenchendo o "vazio", o "fora" que se dobra em fluxo de forças que subjetiva, que constrói sujeitos-forma, formas que se alternam, que se transformam, que nunca terminam de fazer-se. Escritaexperiência que não se coloca no jogo do "verdadeiro ou falso", mas que é sempre uma ficção, algo construído, que passa a existir a partir do vivido. E assim as discussões das aulas na disciplina TEGSE atravessam as vidas das estudantes.

O sentido de uma escrita que desafia o pensamento e o vivido está presente na narrativa de Amanda, algo que se aproxima de uma parrhesia, um "falar francamente", uma "coragem da verdade" (GROS, 2004).

Fico triste de verdade por saber como as coisas são, mas é melhor assim que viver mentiras. Essas aulas, as discussões, os textos têm mexido muito comigo! E descobri verdades não muito legais de se ver... Minha família é machista. Todo mundo aqui em casa é, inclusive minha mãe. Ela é submissa de uma forma que eu não aceitaria ser, mas é normal para ela. Ela se conforma e diz que 'é assim mesmo'. [...] Como não pude perceber isso? Como fiquei 
cega por tanto tempo? Eu não sei, não sei mesmo o que pensar! É estranho saber que seria diferente se eu fosse homem. É difícil aceitar. [...] Eu só queria fazer essa disciplina para saber como falar disso com meus alunos e olha o que está acontecendo! O mundo está mudando, a minha forma de ler o mundo está mudando. Estou rompendo o casulo mais um pouquinho. [...] Minha adolescência se baseou no meu gênero. E como não tenho pênis, saí perdendo. É absurdo! Por alguns (muitos) genes, pelo amor de Deus, gente! (AMANDA).

Coragem da verdade: "a parrhesia supõe uma adesão do falante a seu enunciado; trata-se de enunciar uma verdade que constitui uma convicção pessoal". Uma fala perigosa: "a parrhesia supõe coragem, porque se trata quase sempre de uma verdade que pode ferir o outro e que assume o risco de uma reação negativa por parte dele" (GROS, 2004, p. 157). Dizer o verdadeiro: "É a abertura que faz com que se diga, com que se diga o que se tem a dizer, com que se diga o que se tem vontade de dizer, com que se diga o que se pensa dever dizer porque é necessário, porque é útil, porque é verdadeiro" (FOUCAULT, 2011, p. 327).

Na parrhesia só pode haver verdade. Onde não houver verdade não há franco-falar. A parrhesia é a transmissão nua, por assim dizer, da própria verdade. A parrhesia assegura da maneira mais direta essa parádosis, esse trânsito do discurso verdadeiro de quem já o possui para quem deve recebê-lo, deve dele impregnar-se, deve poder utilizá-lo e deve poder subjetivá-lo (FOUCAULT, 2011).

A escrita de Amanda é uma escrita verdadeira. Não uma escrita-verdade, que se pretenda totalizante ou rígida e que se coloca no jogo verdade/ falsidade. Uma escrita verdadeira por ser escritaexperiência. Amanda fala diretamente de sua família, algo que para ela é motivo de tristeza, de angústias. "Perde o chão". Muda o foco - ou as lentes: vê de outros modos algo que sempre esteve ali presente em seu cotidiano, em sua vida. Ela diz: "Eu só queria fazer essa disciplina para saber como falar disso com meus alunos e olha o que está acontecendo! O mundo está mudando, a minha forma de ler o mundo está mudando. Estou rompendo o casulo mais um pouquinho.” Romper o casulo e constatar o machismo como racionalidade que atravessa e constitui seus familiares, que atravessa e constitui a si própria. Ela se vê nesse sistema, mas, a partir da disciplina, ela ocupa outro lugar: de alguém que pode pensar sobre isso, usar ferramentas conceituais que "fazem sentido" diante das experiências cotidianas.

Uma escrita verdadeira, um franco-falar a si mesma. Entendo aqui as limitações dessa parrhesia que não se torna pública, ou seja, que não é dita aos outros, pelo menos não diretamente. Considero, entretanto, que o dizer verdadeiro da escrita de Amanda no diário de bordo possui também seu caráter político. Escrever no diário de bordo é também produzir um outro mundo, é inventar possibilidades de dizer(-se) nesse mundo. Uma escrita que se associa ao que é dito nas aulas, ao modo como a própria estudante se posiciona nessas aulas, mas também no seu cotidiano familiar. Um franco-falar, portanto, que funciona como experiência, que produz dessubjetivação.

A partir das aulas da disciplina TEGSE, a estudante se percebe imersa nas relações de poder de gênero, ou seja, em relações sociais que funcionam a partir dos enquadramentos e normatizações de gênero. Ao tomar o conceito de gênero como relacional, uma construção social, cultural e histórica das diferenças biológicas e das desigualdades entre sujeitos de gênero - femininos e masculinos (LOURO, 2001), a estudante narra, em um "falar francamente", as "verdades" que descobriu: "Minha família é machista. Todo mundo aqui em casa é, inclusive minha mãe". Como racionalidade, o machismo se coloca para os distintos sujeitos, masculinos e femininos, direcionando suas ações e pensamentos, comandando a construção de seus corpos. Essa racionalidade incide sobre os sujeitos de forma diversa: "É estranho saber que seria diferente se eu fosse homem [...] E como não tenho pênis, saí perdendo. É absurdo! Por alguns (muitos) genes, pelo amor de Deus, gente!". A estudante demarca o modo como têm sido pensadas, social, cultural e historicamente, as relações entre os gêneros: reguladas pelo discurso biológico, pautadas em distinções anatômicas e fisiológicas dos sexos.

Sujeitos masculinos e femininos ocupam distintas posições de sujeito em função do gênero assumido, algo que não se resume às relações binárias que pressupõem masculino e feminino como polos opostos, relacionando-se em uma lógica de dominação-submissão. Amanda problematiza a posição 
de sujeito assumida pela mãe - "Ela é submissa de uma forma que eu não aceitaria ser" - e nesse jogo também define um lugar para si, uma posição de insubmissão, seja como mulher, como filha, como futura professora. Pensando com Foucault (2006, p. 276), a análise do exercício do poder nos remete às relações humanas, "relação em que cada um procura dirigir a conduta do outro". São, portanto, relações móveis, reversíveis, instáveis, que não são dadas de uma vez por todas e que se encontram em diferentes níveis e sob diferentes formas. Outro aspecto evidenciado por Foucault (2006, p. 276) é que nas relações de poder há necessariamente possibilidade de resistência, ou seja, "só é possível haver relações de poder quando os sujeitos forem livres".

Nesse jogo, como pensar as posições de sujeito ocupadas por Amanda e seus familiares? Se for sempre possível a resistência - as pequenas ou grandes transgressões, as astúcias, subterfúgios - ainda poderemos pensar em uma posição de perpétua dominação do outro? Talvez a ideia não seja polarizar as posições de sujeito de Amanda e sua mãe - esta como submissa e aquela como resistente e transgressora -, mas entendê-las nesse jogo das relações de poder. Amanda não se dá conta das possíveis resistências e parece colocar a mãe no lugar da completa captura. Entretanto, pensando com Foucault (2006), nas relações de poder, a submissão apontada por Amanda me parece uma posição estratégica, da qual o poder também é exercido, mesmo que não sob a forma de uma grande libertação.

Com a escrita de Amanda é possível pensar a experiência como ficção e como verdade: "saber como as coisas são [...] é melhor [...] do que viver mentiras". Experiências sendo tecidas nas relações de forças que provocam deslocamentos, que fazem suspeitar de valores e crenças naturalizadas, que permitem problematizar, "dar um passo atrás": "Como não pude perceber isso? Como fiquei cega por tanto tempo? Eu não sei, não sei mesmo o que pensar!". Nesse fluxo de forças, a escrita no diário de bordo parece funcionar como uma "escrita transgressora" - do pensamento, dos limites. Processo que permite a Amanda questionar-se sobre sua família. Possibilita a mim, professorpesquisador, mergulhar no processo da escrita nos diários e compreender que as estudantes não demonstram quem "realmente" são, nem mesmo olham-se "de fora", como se houvesse essa oposição interior/ exterior, uma essência ou uma consciência autônoma. O olhar é sobre o movimento constitutivo da subjetividade, problematizando-o a partir das experiências provocadas pelas aulas da disciplina e pela narrativa de si no diário.

\section{Brevíssimas conclusões}

A partir das análises construídas neste artigo, considero relevante pensar que as estudantes de Pedagogia são sujeitosdocentes se construindo e, no sentido ético, a formação docente integra os processos por meio dos quais um sujeito constrói regras de existência e conduta. A disciplina TEGSE coloca em jogo essa formação, aciona relações de poder e acirra as tensões na relação com as escolas e os modos como as temáticas de sexualidades e relações de gênero circulam e são produzidas nesses espaços e na sociedade. Entendendo que a subjetividade não se remete a uma substância, mas a uma "maneira de se relacionar consigo mesmo para se construir, se elaborar" (GROS, 2008, p. 128), o sentido de formação docente se aproxima daquele atribuído por Foucault (2009, p. 12) à experiência: algo que possibilita "desgarrar al sujeto de si mismo, de manera que no sea ya el sujeto como tal, que sea completamente outro de sí mismo, de modo de llegar a su aniquilación, su disociación". Sair de si mesmo, desprender-se de si mesmo, não para tornar-se um objeto de observação introspectiva, que seria preciso descrever e estudar, mas permanecer presente a si mesmo, atento a si próprio, algo "da ordem de esforço de vigilância que intensifica a imanência a si mesmo" (GROS, 2008, p. 131). Experiência como encontro ou relação com algo que se prova, que se experimenta. Experiência que não poderá ser experimentada por outros do mesmo modo, com a mesma intensidade, mas que se torna motivo de problematização durante as aulas da disciplina TEGSE e dos diários de bordo.

A partir das escritasnarrativas das estudantes é possível pensar na dimensão formativa da experiência que está, para além do acúmulo de vivências em um processo linear, na sua incompletude 
e instabilidade. O exercício de escrita de si no diário de bordo também se dá pelo movimento de fazer perguntas que geram outras perguntas, um movimento que possibilita às estudantes de Pedagogia pensar de outros modos as situações que já tinham sido vivenciadas a partir dos debates nas aulas. Uma formaçãoexperiência que não supõe a formatação de um modelo docente, um sujeito-substância, rígido, capaz de enfrentar todos os desafios ex-postos nas escolas de modo tranquilo e asséptico. É o cuidar de si para cuidar do outro: "o cuidado de si não é uma atividade solitária, que cortaria do mundo aquele que se dedicasse a ele, mas constitui, ao contrário, uma modulação intensificada da relação social." (GROS, 2008, p. 132).

Chama atenção o modo como as narrativas das estudantes remetem a um processo de ver coisas muito óbvias, mas que buscamos discutir como parte de um processo de naturalização das sexualidades e das relações de gênero. Nesse caso, as narrativas funcionariam, ao mesmo tempo, como capturas momentâneas do processo de constituição da experiência de si (LARROSA, 2002) e como mecanismo de subjetivação. Nesse sentido, me inspiro no referido autor para pensar na proposta dos diários de bordo como "um gesto de interrupção" que dá condições para que a experiência aconteça, e que requer

[...] parar para pensar, parar para olhar, parar para escutar pensar mais devagar [...]; parar para sentir, sentir mais devagar, demorar-se nos detalhes, suspender a opinião, suspender o juízo, suspender a vontade, suspender o automatismo da ação [...], falar sobre o que nos acontece, aprender a lentidão. (LAROSSA, 2014, p. 24).

As estudantes produzem seus diários, constituindo um certo sentido do que são, dos lugares que ocupam na sociedade, enquanto mulheres, estudantes, professoras em formação, colocando-se por meio da escrita como "sujeito experimentador". Foucault (2009) nos diz que seu trabalho foi construir "livros-experiência", processos de escrita que proporcionam a experiência da mudança e transformação, um trabalho para impedir-lhe de ser "sempre o mesmo". Quando argumenta isso, ele diz pensar na experiência como um empreendimento de dessubjetivação, que faz o sujeito "desgarrar-se de si mesmo". Estou, desse modo, me apropriando da ideia da escrita produzida pelas estudantes nos diários de bordo como uma escrita que pode dizer de processos de dessubjetivação, materializados em diáriosexperiência: ao finalizá-los as estudantes não são mais as mesmas.

\section{REFERÊNCIAS}

BUTLER, Judith. Corpos que pesam: sobre os limites discursivos do "sexo". In: LOURO, Guacira L. (Org.). O corpo educado: pedagogias da sexualidade. 2. ed. Belo Horizonte: Autêntica, 2001. p. 151-172.

. Problemas de gênero - feminismo e subversão da identidade. Rio de Janeiro: Civilização Brasileira, 2003.

CASTRO, Roney Polato de. Experiência e constituição de sujeitosdocentes: relações de gênero, sexualidades e formação em Pedagogia. 2014. 256f. Tese (Doutorado em Educação) - Faculdade de Educação, Universidade Federal de Juiz de Fora, Juiz de Fora, MG, 2014.

FOUCAULT, Michel. História da sexualidade II: o uso dos prazeres. 9. ed. Trad. Ma Thereza da Costa Albuquerque. Rio de Janeiro: Graal, 2001.

. Ética, Sexualidade, Política. 2. ed. Trad. Elisa Monteiro e Inês Autran Dourado Barbosa. Rio de Janeiro: Forense Universitária, 2006. (Ditos \& Escritos V).

El yo minimalista e otras conversaciones. Buenos Aires: La marca Editora, 2009.

. A hermenêutica do sujeito: curso dado no Collège de France (1981-1982). Trad. Márcio Alves da Fonseca e Salma Tannus Muchail. 3. ed. São Paulo: Martins Fontes, 2011.

GROS, Frédéric. A parrhesia em Foucault (1982-1984). In:

Marcos Marcionilo. São Paulo: Parábola, 2004. p. 155-166.

(Org.). Foucault: a coragem da verdade. Trad.

O cuidado de si em Michel Foucault. In: RAGO, Margareth; VEIGA-NETO, Alfredo (Org.). Figuras de Foucault. Belo Horizonte: Autêntica, 2008. p. 127-138. 
LARROSA, Jorge. Tecnologias do Eu e Educação. In: SILVA, Tomaz Tadeu da (Org.). O sujeito da educação: estudos foucaultianos. Petrópolis, RJ: Vozes, 2002. p. 35-86.

. Nietzsche \& a educação. 2. ed. Trad. Semíramis Gorini da Veiga. Belo Horizonte: Autêntica, 2005.

Tremores: escritos sobre experiência. Trad. Cristina Antunes e João Wanderley Geraldi. Belo Horizonte: Autêntica, 2014.

LOPES, Luiz Paulo da Moita. A performance narrativa do jogador Ronaldo como fenômeno sexual em um jornal carioca: multimodalidade, posicionamento e iconicidade. Revista da ANPOLL, v. 2, n. 27, p. 128-157, 2009. Disponível em: <http://www.anpoll.org.br/revista/index.php/revista/article/viewFile/146/156>. Acesso em: 11 mar. 2013.

LOURO, Guacira Lopes. Pedagogias da sexualidade. In: lidade. 2. ed. Belo Horizonte: Autêntica, 2001. p. 09-34.

(Org.). O corpo educado: pedagogias da sexua-

MARSHALL, James D. Michel Foucault: pesquisa educacional como problematização. In: PETERS, Michael A.; BESLEY, Tina (Org.). Por que Foucault? Novas diretrizes para a pesquisa educacional. Porto Alegre: Artmed, 2008. p. 25-39.

MATTOS, Andrea Machado de Almeida. Narrativas, identidades e ação política na pós-modernidade. Educação \& Sociedade, Campinas, v. 31, n. 111, p. 587-602, abr./jun. 2010. Disponível em: <http://www.scielo.br/pdf/es/ v31n111/v31n111a15.pdf $>$. Acesso em: 11 mar. 2013.

MISKOLCI, Richard. Teoria Queer: um aprendizado pelas diferenças. Belo Horizonte: Autêntica/UFOP, 2012.

ORTEGA, Francisco. Amizade e estética da existência em Foucault. Rio de Janeiro: Graal, 1999.

RAGO, Margareth. A aventura de contar-se: Foucault e a escrita de si de Ivone Gebara. In: SOUZA, Luiz Antônio F.; SABATINE, Thiago T.; MAGALHÃES, Boris R. (Org.). Michel Foucault: sexualidade, corpo e direito. São Paulo: Cultura Acadêmica, 2011. p. 01-18. Disponível em: <http://www.marilia.unesp.br/Home/Publicacoes/foucault_book.pdf>. Acesso em: 23 jun. 2012.

SARLO, Beatriz. Tempo passado: cultura da memória e guinada subjetiva. Trad. Rosa Freire d'Aguiar. São Paulo: Companhia das Letras, 2007.

Recebido em: 27.08 .2015

Aprovado em: 04.02.2016 